\title{
PGD in carriers of reciprocal translocations by aCGH in trophectoderm biopsy and deffered cycle transfer
}

\section{PGD em carreadores de translocações recíprocas por biopsia de trofectoderma por aCGH e transferência em ciclo diferido}

Maria Eugenia Ducatelli, Andressa Grazziotin Mondadori, Fabian Coco, Sebastian Neuspiller, Judith Mincman, Roberto Coco

Fecunditas-Reproductive Medicine Institute

Accredited Redlara center

www.PGD-Fecunditas.com.ar

\begin{abstract}
Objective:It is well known that reciprocal and Robertsonian translocations carriers have increased risks of producing aneuploidies gametes associated with the meiotic multivalent, which ones abort spontaneously or end with the birth of an abnormal child. Method: We present our preliminary experience with 8 (eight) cases of PGD of balanced translocations with trophectoderm biopsy, genetic study by aCGH and deffered transfer. Seven cases were reciprocal translocations and only one was a Robertsonian translocation. From reciprocal translocations twenty two blastocysts were biopsied and ten from Robertsonian translocations.

Results: Amongst the first group, a $41 \%$ resulted in a normal aCGH, a $46 \%$ abnormal due to malsegregation of the multivalent, and a $13 \%$ aneuploid not related to the meiotic quadrivalent. In the Robertsonian translocation a $60 \%$ was normal, a $10 \%$ unbalanced by malsegregation of the meiotic trivalent and a $30 \%$ aneuploid not related to translocation. Surprisingly most of the abnormalities (90\%) were due to adjacent type 2 segregation and malsegregation 3:1, which imply important chromosomal unbalance. Out of the 8 (eight) performed cycles, only 4 were transferred with a normal aCGH blastocyst. Three of them achieved the pregnancy.

Conclusion: Taking into account the results achieved with biopsy in day 3 and fresh transfer, it seems that the results in day 5 and deferred transfer are much better. Probably the biopsy performed in an embryo that reach the maximum stage of development in vitro and the transfer in a cycle with an endometrium more physiologically prepared are the main reasons for the best results. Key-words: PGD; carriers ; translocations; aCGH ; trophectoderm biopsy; deffered cycle transfer
\end{abstract}

\section{RESUMO}

Objetivo: É bem sabido que os carreadores de translocações recíprocas e Robertsoniana têm risco aumentado de produzirem gametas aneuploides associados com polivalencia meiótica, que abortar espontaneamente ou chegam ao nascimento de uma criança anormal. Método: Apresentamos nossa experiência preliminar com 8 (oito) casos de PGD de translocações equilibradas com estudo de trofectoderma por biópsia e aCGH, com transferência diferida. Sete casos foram transloca- ções recíprocas e apenas uma era translocação Robertsoniana. Das translocações recíprocas 22 blastocistos foram biopsiados e 10 de translocações Robertsonianas. Resultados: No primeiro grupo, $41 \%$ resultou num aCGH normal, $46 \%$ anormais devido à separação anômala do multivalente, e $13 \%$ de aneuploidias, não relacionadas com o quadrivalente meiótico. Na translocação Robertsoniana $60 \%$ eram normais, $10 \%$ desbalanceados por separação anômala do trivalente meiótico e 30\% aneuplóides não relacionados com a translocação. Surpreendentemente, a maioria das alterações $(90 \%)$ foram devidos a segregação adjacente tipo 2 e má-segregação 3:1, que implicam em importante desequilíbrio cromossômico. Dos 8 ciclos realizados, apenas 4 foram transferidos com um blastocisto aCGH normal. Três deles resultaram em gravidez.

Conclusão: Tendo em conta os resultados obtidos com biopsia no dia 3 e a transferência à fresco, parece que os resultados no dia 5 e transferência diferida são muito melhores. Provavelmente, a biópsia realizada num embrião que atinge a fase máxima de desenvolvimento in vitro e transferência em ciclo com endométrio mais fisiologicamente preparado são as razões principais para os melhores resultados

Palavras-chave: PGD, carreadores; translocações; aCGH; biopsia de trofectoderma; transferência em ciclo diferido.

\section{INTRODUCTION}

The incidence of balanced translocation in newborn general population is $1 / 500$, being much bigger in infertile population.

It is well know that the carrier of reciprocal and Robertsonian translocation have an increased risk of producing gametes with chromosome imbalances of the involved chromosomes in the rearrangement and beside of other chromosomes, probably by interchromosomic effect. The abnormal gametes originate abnormal embryos, which abort spontaneously or end in malformed babies. The PGD is becoming into a valid alternative of prenatal diagnosis. We present our preliminary experience with 8 (eight) cases of PGD of balanced translocations with trophectoderm biopsy, genetic study by aCGH and differed transfer.

\section{PATIENTS AND METHODS}

The couples accessed to PGD for various reasons: recurrent aborts (4 couples), stillborn with inherited chromosome rearrangement (1 couple), primary sterility (2 
couples), family history of Down Syndrome (1 couple). The average age of the patients was 31.6 years old, being the youngest of 24 years old and the elder of 39 years old. The different translocations were:

1) $46, \mathrm{XX}, \mathrm{t}(6 ; 10)(\mathrm{q} 13 ; \mathrm{q} 24) ; 2) 46, \mathrm{XX}, \mathrm{t}(9 ; 13)(\mathrm{q} 21 ; \mathrm{q} 21.2) ; 3)$ $46, \mathrm{XX}, \mathrm{t}(9 ; 13)(\mathrm{q} 34.3 ; \mathrm{q} 14.3)$; 4) 46,XX,t(1;8)(q41-42;q12); 5) $46, X X, t(6 ; 7)(q 23 ; q 34) ; 6) 46, X X, t(10 ; 18)(q 24 ; q 21) ; 7)$ $46, \mathrm{XY}, \mathrm{t}(3 ; 6)(\mathrm{q} 26 ; \mathrm{q} 24)$ and 8$) 45, \mathrm{XY}, \mathrm{t}(13 ; 21)(\mathrm{q} 10 ; \mathrm{q} 10)$.

Prior to the PGD all women were checked for ovarian follicular reserve, with the basic hormonal profile and the antral follicles count with ultrasonography of the ovaries. In males semen was checked. All female patients were stimulated with recombinant gonadotropins and $\mathrm{GnRH}$ antagonists according to standard protocols. All cases were performed with ICSI procedure. The normal fertilized oocytes were cultivated during 5 or 6 days until reach the blastocyst stage. In day 3 a hole in the pellucid membrane of the cleavage embryos with 5 or more cells was done with laser shots, to facilitate the trophectoderm biopsy in the hatching blastocyst. Once the biopsy was performed, all blastocysts were vitrified. The trophectoderm cells were processed with the aCGH using the BlueGnome's ${ }^{\mathrm{TM}} 24$ Sure kit. The endometrium was prepared for the transfer with estrogens and progesterone. Only a normal molecular karyotype blastocyst was transferred.

\section{RESULTS}

The number of aspirated oocytes varied from 6 to 23 (x: $12,5)$, the normal fertilized oocytes from 2 to $18(x: 8,88)$ and the number of biopsied blastocysts from 2 to 10 ( $x: 4)$. The number of normal embryos varied from 1 to 6 (x: $1,88)$. All of them had at least a normal embryo, except case with $10 ; 18$ translocation.

Out of the 22 biopsied blastocysts corresponding to reciprocal translocations, 9 resulted normal $(41 \%), 10$ abnormal due to malsegregation of the quadrivalent (46\%) and 3 with abnormalities not related to translocation (13\%). Out of the ten biopsied blastocysts corresponding to Robertsonian translocation, six were normal $(60 \%)$, one related to malsegregation of the trivalent (10\%) and three with chromosome abnormalities no related to the translocation (30\%).

In the reciprocal translocation group, the observed aneuploidies were due to: Adjacent type 1 segregation (1 blastocyst), Adjacent type 2 (5 blastocysts) and Segregation 3:1 (4 blastocysts). In PGD for male Robertsonian translocation, the only related aneuploidy was due to a 2:1 malsegregation. The three not related chromosome anomalies were study with STRs linked to the aneuploid chromosomes, which ones showed a maternal origin. Four patients were transferred with one devitrified blastocyst, three of them had not transfer yet and the case with translocation 10;18 can not be transferred because the only balstocyst resulted chromosomally abnormal. Of the four women transferred three become pregnant.

\section{DISCUSSION}

The results obtained in these series of 8 cycles of PGD of reciprocal translocations, allows us to conclude that all fertilized oocytes reached the blastocyst stage, all of them were successfully biopsied, obtaining several cells from the trophoectoderm, a genetic diagnosis was obtained in all biopsed blastocysts, and at least one blastocyst with normal balanced karyotype was achieved for transfer, except one case (translocation 10, 18).

Given that carriers of reciprocal translocations have a theoretical risk of $80 \%$ to produce abnormal gametes and $75 \%$ for Robertsonian translocation carriers due to malsegregation of the multivalent, it was reduced to $46 \%$ in blastocysts of reciprocal translocation carriers and $10 \%$ in the Robertsonian translocation carriers. Both values are considerably lower than the reported data in blastomere biopsy at third day, which is around to $80 \%$ for reciprocal translocation (Harper et al, 2010; Yinghui et al, 2012) and $30 \%$ for the Robertsonian translocations (Chang et al, 2012). Also, we observed a $13 \%$ of abnormalities not related with the reciprocal translocations. These aneuploidies may be due to a interchromosomic effect during the meiotic division in the carrier or due to meiotic errors of the couple. We tried to elucidate the origin of such aneuploidies using polymorphic markers or STRs linked to aneuploid chromosomes of both partners, but we don't have yet the results. In contrast, in the case of the patient with the Robertsonian translocation, the percentage of abnormalities not related was $30 \%$ and the study with STRs linked to the chromosome aneuploides allowed us to rule out any interchromosomic effect and confirm that the aneuploidies occurred by meiotic errors in the couple (Ducatelli et al, 2011).

The high rate of aneuploid blastocysts in this series was higher than one might expect. It had been recognized that there was some selection during preimplantation development in vitro, but judging by the results obtained with the array $\mathrm{CGH}$, it does not seem to be as efficient as believed, even in the imbalances that involve the gain or the loss of an entire chromosome, like occur in adjacent 2 or 3:1 segregations, that in our series was $90 \%$.

We believe that three of four transfers with pregnancy is an excellent incentive to continue performing the PGDs in blastocyst stage and deferred transfer. Our experience with biopsy at third day in carriers of reciprocal translocations was $13 \%$ ( $n: 30$ cycles) and $25 \%$ in Robersonian translocations ( $\mathrm{n}$ : 16 cycles) agreeing with the data of the last ESRHE PGD Consortium that showed pregnancy rates in carriers of reciprocal and Robertsonian translocations around $14 \%$ and $21 \%$, respectively. (Goosens et al, 2012). Although the numbers of cases is so low, the pregnancy rate achieved is more promising than the obtained with biopsy at third day and fresh transfer. The fact to biopsy an embryo with the maximum stage of development in vitro and to transfer it in a physiological medium in a deffered cycle non super stimulated may be the causes of a better implantation rate. (Roque et al, 2013)

\section{REFERENCES}

Harper, J.C., Coonen, E., De Rycke, M., Harton, G., Moutou, C., Pehlivan, T., Traeger-Synodinos, J., Van Rij, M.C., Goossens, V. ESHRE PGD Consortium data collection $X$ : cycles from January to December 2007 with pregnancy follow-up to October 2008. Hum. Reprod. 2010; 25, 2685-2707.

Yinghui Ye, Yuli Qian, Chenming Xu, Fan Jin. Meiotic segregation analysis of embryos from reciprocal translocation carriers in PGD cycles. Reprod Biomed Online 2012; 24(1): 83-90

Ducatelli ME, Mondadori G, Mincman J, Coco R. Diagnóstico preimplantatorio por fusión céntrica $13 ; 21$ realizado por metodología molecular. Premio al mejor trabajo de Investigación Clínica presentado en el VI Congreso de la Sociedad de Andrología y $\mathrm{V}$ Congreso de la Asociación Iberoamericana de Sociedades de Andrología, Buenos Aires, 19-21 Abril 2012.

Chang EM, Han JE, Kwak IP, Lee WS, Yoon TK, Shim $\mathrm{SH}$. Preimplantation genetic diagnosis for couples with a Robertsonian translocation: practical information for genetic counseling. J Assist Reprod Genet. 2012 ; 29(1):67-75.

Goossens V, Traeger-Synodinos J, Coonen E, De Rycke M, Moutou C, Pehlivan T, Derks-Smeets IAP, Harton G. ESHRE PGD Consortium data collection XI: cycles from January to December 2008 with pregnancy follow-up to October 2009. Human Reproduction, 2012; 27 (7): 1887-1911.

Roque M, Lattes K, Serra S, Sola I, Geber S, Carreras R, Checa MA. Fresh embryo transfer versus frozen embryo transfer in in vitro fertilization cycles: a systematic review and meta-analysis. Fertil Steril 2013; 99: 156-162. 